\title{
Pendampingan Mahasiswa Dalam Mengucapkan Bahasa Inggris Standar Berbasis Kendala Fonologis Bahasa Daerah
}

\author{
Arafiq, Nurachman Hanafi, Nur Ahmadi, Atri Dewi Azis
}

Program Studi Pendidikan Bahasa Inggris Universitas Mataram

\section{Alamat korespondensi : arafiq@unram.ac.id}

\begin{abstract}
ABSTRAK
Kegiatan pengabdian ini bertujuan untuk memberikan pendampigan pengucapan Bahasa Inggris dengan memperhatikan kendala bunyi Bahasa Daerah sebagai dasar dalam merencanakan pola pendampingan dan sintagmatik materi. Kegiatan diawali dengan penyampaian materi, yakni peta kendala fonologis penutur Bahasa Sasak, Bahasa Bima, dan Bahasa Sumbawa, strategi pengucapan terkait dengan bunyibunyi yang dianggap bermasalah secara fonologis akibat dari pengaruh negatif Bahasa Daerah dalam pembelajaran Bahasa Inggris (negative transfer of mother toungue). Langkah selanjutnya adalah pendampingan. Pendampingan ini dilakukan secara daring dengan platform google meet dengan membagi peserta dalam 3 (tiga) kelompok yang dibimbing oleh masing-masing satu tim pendamping. Kegiatan ini juga dapat dilakukan secara mandiri oleh peserta diwaktu yang lain karena materi juga disiapkan di Spada Unram. Tahap selanjutnya adalah proses evaluasi. Berdasarkan hasil evaluasi, peserta mempunyai kesadaran akan kendala fonologis yang dirasakan selama ini dalam mengucapkan bunyi Bahasa Inggris. Dengan kesaradan ini, maka peserta dapat dengan mudah menggunakan strategi dalam meminimalisir atau bahkan menghilangkan kendala tersebut dalam mengucapkan bunyi Bahasa Inggris. Di akhir kegiatan ini, peserta memiliki kepercayaan diri yang lebih baik dalam memproduksi ujaran Bahasa Inggris lisan, khsusunya keterampilan sepaking dan reading.
\end{abstract}

Kata kunci : Kendala fonologis; Bahasa Daerah; Kepercayaan diri; Speaking; Raeding

\section{PENDAHULUAN}

Beberapa penelitian telah membuktikan bahwa pengaruh unsur fonologi bahasa ibu terhadap pemerolehan Bahasa Inggris cukup signifikan. Avery \& Ehrlich (1992) menemukan bahwa variasi aksen Bahasa Inggris sangat dipengaruhi oleh latar belakang bahasa ibu penuturnya. Hal ini dapat dilihat dari adanya istilah Bahasa Inggris eksen Spanyol, Bahasa Inggris eksen Cina, Bahasa Inggris eksen Jepang dan lain sebagainya yang ditamatkan oleh penutur asli Bahasa Inggris kepada penutur non asli. Hal ini berarti bahwa kesalahan dalam memprodiksi bunyi bahasa asing bukan semata-mata disebabkan oleh usaha yang tidak sistematis tetapi hal itu lebih disebabkan oleh refleksi dari perbendaharaan bunyi, kaidah penggabungan bunyi, serta pola tekanan dan intonasi bahasa ibu yang dimiliki oleh penutur (Swan \& Smith, 1987).

Mahasiswa penutur tiga Bahasa daerah di Nusa Tenggara Barat, yakni Bahasa Sasak, Bahasa Samawa, dan Bahasa Bima tidak terkecuali mengalami kesulitan dalam memproduksi bunyi-bunyi tertentu dalam Bahasa Inggris. Kesulitan itu antara lain disebabkan oleh perbedaan bunyi Bahasa Inggris dengan bunyi ketiga Bahasa daerah tersebut sebagai bahasa ibu mahasiswa. Arafiq, dkk. (2019) menemukan bahwa mahasiswa S1 Pendidikan Bahasa Inggris FKIP Universitas Mataram penutur Bahasa Daerah di NTB memiliki beberapa kendala dalam mengucapkan bunyi-bunyi Bahasa Inggris. Mahasiswa penutur Bahasa Bima memiliki kesulitan dalam mengucapkan kata Bahasa Inggris yang mengandung bunyi vokal tengah rendah /ə/ yang dapat beralernasi menjadi vokal tinggi belakang /e/ atau vokal tinggi depan /i/ dan Daerah di NTB Kenyataan ini semakin diperparah oleh sikap penutur yang terkadang 
memilki resistensi untuk mengucapkan bunyi-bunyi Bahasa Inggris karena takut salah dan ditertawakan oleh mahasiswa lainnya. Hal yang sama juga terjadi pada penutur Bahasa Sasak dan Bahasa Samawa. Berkaitan dengan ini Zhang (2009) mengatakan bahwa sikap terhadap bahasa target dapat mempengaruhi ketercapaian pengucapan bunyi yang tepat.

Berdasarkan uraian di atas, maka permasahan yang dihadapi oleh sasaran kegiatan Pengabdian kepada Masyarakat ini cukup kompleks. Permasalahan yang pertama adalah masih kuatnya pengaruh bunyi bahasa daerah terhadap usaha mempelajari Bahasa Inggris. Hal ini sering menyebabkan mahasiswa merasa malu dan tidak percaya diri dalam mempelajari Bahasa Inggris sehingga hasil/prestasi belajar Bahasa Inggris mahasiswa tidak maksimal. Oleh karena itu, dengan memperhatikan permasalahan tersebut, maka kegiatan pengabdian kepada masyarakat kepada mitra mahasiswa yang tergabung dalam Local Language English Speakers of West Nusatenggara dalam bentuk pendampingan bagaimana mengucapakan Bahasa Inggris Berbasis Kendala Fonologis Bahasa Daerah di NTB dianggap penting dan relevan untuk dijadikan sebagai selah satu kegiatan pengabdian kepada masyarakat ini.

\section{METODE KEGIATAN}

Pendekatan/Metode yang digunakan dalam kegiatan ini adalah pendekatan/metode partisipatif. Pendekatan/metode ini berorientasi pada upaya peran serta mitra secara langsung dalam berbagai proses dan tahap pelaksanaan kegiatan, mulai dari perencanaan, pelaksanaan, sampai pada evaluasi kegiatan. Mitra sasaran tidak hanya bertindak sebagai objek kegiatan, tetapi juga sebagai pelaku kegiatan. Sementara itu, Tim Pelaksana hanya bertindak sebagai fasilitator dan motivator. Oleh karena Pandemi Covid-19, kegiatan ini dilaksanakan melalui daring dengan memanfaatkan SPADA Universitas Mataram sebagai media dalam pelaksanaan kegiatan klasikal. Namun demikian, tidak mengurangi tahapan pelaksanaan sesuai dengan yang direncanakan seperti berikut ini.

\section{Tahap Konfirmasi Rencana Kegiatan dengan Sasaran}

Konsfirmasi rencana kegiatan akan disampaikan kepada sasaran, sekaligus membicakaran waktu, serta hal-hal teknis lainnya supaya terbangun sinergisitas antara Tim Pelaksana dengan sasaran.

\section{Tahap Pelaksanaan Kegiatan}

Kegiatan pelatihan dilakukan dengan presentasi dan diskusi dan dilanjutkan dengan pendalaman materi melalui praktek (simulasi) di dalam secara daring dengan pendampingan yang dilakukan oleh Tim Pelaksana. Materi pendampingan dalam kegiatan ini adalah pemetaan bunyi Bahasa Inggris dan bahasa daerah yang ada di NTB (Bahasa Sasak, Bahasa Samawa, dan Bima), phonetics articulatory, strategi pengucapan bunyi Bahasa Inggris Standar.

\section{Evaluasi Pelaksanaan Kegiatan}

Evaluasi terhadap capaian target kegiatan dilakukan dengan menilai ketercapaian tujuan pengabdian. Teknik evaluasi dilakukan dengan pengamatan dan tanya jawab langsung kepada perseta palatihan, serta penilaian berbasis proyek (project-based assesment).

\section{Koordinasi Pelaksanaan Kegiatan}

\section{HASIL KEGIATAN}

Koordinasi rencana pelaksanaan kegiatan disampaikan kepada mitra sasaran Local Language English Speakers of West Nusatenggara (LLESWN) dilaksanakan pada 6 April 2020. Pertemuan ini dilaksanakan secara daring dengan menanfaatkan dengan menggunakan aplikasi Google meet. Pertemuan daring ini diikuti oleh mitra dan semua anggota tim pengabdian. Pertemuan ini bertujuan untuk menetapkan jenis dan metode yang digunakan 
dalam kegiatan tersebut. Hasil sosialisasi disepakati beberapa hal terkait dengan kegiatan yang dimaksud. Pertama, pelaksanaan kegiatan dilaksanakan melalui daring SPADA Unram dengan materi pelatihan tentang teori fonologi, kendala-kendala bunyi Bahasa Inggris bagi penutur Bahasa Daerah di NTB, kemudian strategi-strategi yang dilakukan dalam pengucapan bunyi Bahasa Inggris. Kedua, waktu pelaksanaan diupayakan untuk dilaksanakan di hari libur sehingga tidak mengganggu perkuliahan mahasiswa sasaran kegiatan. Terakhir, diharapkan kegiatan ini dilaksanakan secara intensif dan berkala. Disepakati bahwa kegiatan dilaksanakan pada 29 Agustus 2020 dengan memanfaatkan SPADA Unram.

\section{Pendampingan Pengucapan Bahasa Inggris Berbasis Kendala Fonologis Bahasa Daerah di NTB}

Pelaksanaan Kegiatan Pengabdian ini dilaksanakan pada 29 Agustus 2010 secara daring dengan menggunakan SPADA Unram. Materi yang digunakan dalam kegiatan ini diunduh secara lengkap sehingga ketika pendampingan dilakukan mahasiswa sudah membuka dan memiliki pemahamaan dasar terkait materi. Terdapat kendala teknis ketika pelaksanaan kegiatan dilakukan. Sistem SPADA Unram masih dalam proses perbaikan, yakni meningkatkan kapasitas sistem, sehingga SPADA tidak bisa diakses, terutama aplikasi BBBnya. Oleh karena demikian, maka tim memutuskan untuk melaksanakan pertemuan melalui google meet. Pelaksanaan dengan google meet berjalan dengan lancar. Semua materi dapat disampaikan dangan baik. Peserta mengikuti kegiatan dengan penuh antusias. Setelah penyampaian materi dilakukan, maka sesi selanjutnya adalah tanya jawab. Pada sesi ini, mahasiswa diberikan waktu untuk bertanya terkait dengan hal-hal yang belum mereka pahami pada saat presentasi materi. Setelah sesi tanya jawab, maka kegiatan selanjutnya adalah latihan pengucapan bunyi-bunyi yang dianggap bermasalah atau sulit diucapkan oleh beberapa mahsiswa penutur Bahasa Daerah di NTB.

Selanjutnya adalah membagi kelompok berdasarkan bahasa ibu. Pada masing-masing kelompok penutur, didampingi oleh satuorang tim untuk melatih mengucapkan kata-kata Bahasa Inggris yang sulit diucapkan. Bagi mahasiswa penutur Bahasa Bima, berapa bunyi yang dianggap sulit adalah bunyi /e/ dengan fitur [lemah, tengah, unrounded] seperti pada kata girl, bird, dan search. Mahasiswa penutur Bahasa Sasak dibimbing dengan melatih mengucapkan bunyi bahasa inggris /f/ dan /v/ dengan fitur [bilabial, frikatif], seperti pada kata football, variation,floor, dan five. Sementara mahssiwa penutur Bahasa Sumbawa sebagian besara memliki kesulitan yang sama dengan mahasiswa penutur Bahasa Sasak. Namun demikian ada beberapa yang juga memiliki kesulitan yang sama seperti mahasiswa penutur Bahasa Bima.

\section{Evaluasi Pelaksanaan Kegiatan}

Evaluasi dilakukan dengan cara observasi (pengamatan) dan performance-based assement terhadap penampilan/keterampilan peserta dalam melakukan pengucapan terhadap kata-kata yang dianggap bermasalah untuk diucapkan oleh semua mahasiswa. Setelah pelaksanaan kegiatan, mahasiswa dapat mempelajari kembalai bagaimana caraatau startegi dalam mengucapkan bunyi-bunyi Bahasa Inggris sesuai dengan standar dengan mengakses kelas daring di SPADA Unram.

\section{KESIMPULAN DAN SARAN}

Kegiatan pendampingan ini dapat dilaksanakan dengan baik, walaupun terdapat beberapa kekurangan, terkait dengan kendala teknis, seperti sistem daring yang sedang 
bermasalah ketika kegiatan dilaksanakan. Secara umum pendampingan ini berjalan sesuai dengan rencana. Mahsiswa sasaran sudah memiliki kesadaran akan bunyi-bunyi yang dianggap sulit mereka ucapkan dan dapat menentukan strategi yang tepat dalam mengucapkannya. Dengan kesadaran yang meningkat, maka kepercayaan diri mahasiswa dalam memproduksi bunyi Bahasa Inggris semakin meningkat, sehigga diharapkan dapat berpengaruh terhadap hasil atau preatasi belajar mereka, terutama terhadap matakulaih keterampilan produktif.

Kegiatan pengabdian dalam bentuk pelatihan, pendampingan dan pembimbingan pengcapan Bahasa Inggris berbasis kendala fonologis bahasa daerah harus dilakukan dengan tepat sasaran sdan dengan pendampingan yang terus menerus sehingga terbangun kesadaran terhadap kendala-kendala bunyi bahasa daerah yang dimiliki oleh mahasiswa yang kemudian dapat memilih strategi untuk melatih dna melatih pengucapannya sehingga kepercayaan diri mereka menjadi lebih bagus dalam memproduksi Bahasa Inggris.

\section{DAFTAR PUSTAKA}

Arafiq, dkk. 2019. Pendampinga Pengelola Taman Narmada dengan Pola English-Integrated Service. Laporan Pengabdian PNBP Universitas Mataram 2019.

Avery, P. \& Ehrlich, S. 1992. Teaching American English Pronunciation. Oxford University Press.

Zhang (2009) Tones, Tonal Phonology, and Tone Sandhi. The Handbook of Chinese Linguistics, First Edition. Edited by C.-T. James Huang, Y.-H. Audrey Li, and Andrew Simpson. (C) 2014 John Wiley \& Sons, Inc. Published 2014 by John Wiley \& Sons, Inc 